\title{
Köken Tartışmaları Ekseninde Katarlara Dair Tarih Yazımındaki Güncel Paradigma Değişikliği ${ }^{*}$

Feyza SAÇMALI ${ }^{* *}$

Kemal ATAMAN ${ }^{* * *}$

Atıf/C: Saçmalı, Feyza \& Ataman, Kemal, (2021). Köken Tartışmaları Ekseninde Katarlara Dair Tarih Yazımındaki Güncel Paradigma Değişikliği, Milel ve Nihal, 18 (1), 41-65.

Öz: Katarlara dair tarih yazımı her ne kadar XIII. yüzyılda başlamışsa da yoğunluk ve ivme kazanması ancak XIX. yüzyıldan sonraya tekabül etmektedir. Katarların tarihindeki gizem zaman zaman ideolojik bakış açılarına imkân vermiş ve bu yaklaşımlar süreç içerisinde birçok safhaya evrilmiştir. 1950'ler öncesi yapılan akademik çalışmalarda, Katarların Maniheist kökenli olduğu ve bu öğretinin IX. yüzyılda Anadolu'da Pavlikenler, X. yüzyılda ise Balkanlar'da Bogomiller üzerinden Güney Fransa ve Kuzey italya Katarlarına geldiği tezi savunulmaktadır. Ancak bu düşüncenin artık terkedilmeye yüz tuttuğunu söylemek mümkündür. Günümüzde, Katarların tarihte hiç var olmayıp Katoliklerin icat ettikleri hayali bir düşman olabileceğini savunan "septik yaklaşım" ortaya çıkmıştır. Bununla beraber Katar tarihçilerinin "septikler" ve "gelenekselciler" olarak ikiye ayrıldığını da görmekteyiz. Bu makalenin amacı, "güncel" paradigma olarak adlandıracağımız, Maniheist kökeni reddetmekle birlikte septik görüşü de birçok noktada eleştiren yeni bir kategori teklif etmektir. Bu amaçla makale, konu etrafında gelişen literatürde tartışılan bu iki kategorinin ne kadar yeterli olduğu meselesini

* Bu makale, Feyza Saçmalı tarafından hazırlanan “XII. ve XIII. yüzyıl Languedoc Bölgesi'ndeki Katolik Kilisesi-Katarlar Çatışmasına Bourdieu'cu Bir Yaklaşım" isimli doktora tezinden üretilmiştir.

** Sorumlu Yazar: Dr., [feyzauznglu@gmail.com] ORCID: 0000-0001-9009-8969.

*** Prof. Dr., Marmara Üniversitesi, İlahiyat Fakültesi, Din Sosyolojisi Anabilim Dalı [kemal.ataman@marmara.edu.tr] ORCID: 0000-0001-5107-8367. 
tarihçilerin mutabık kaldıkları ve ayrıştıkları noktaları analiz edip yorumlayarak ortaya koymaya çalışacaktır.

Anahtar Kelimeler: Katarlar, Hıristiyan heresisi, Bogomiller, Pavlikenler, Düalizm, Katarlar'a dair tarih yazımı.

Current Paradiom Shift in the Cathars' Historiography on the Axis of Debate of the Origin

Citation/C: Saçmalı, Feyza \& Ataman, Kemal, (2021). Current Paradigm Shift in the Cathars' Historiography on the Axis of Debate of the Origin, Milel ve Nihal, 18 (1), 41-65.

Abstract:Although historical writings on Cathars' date back to the Catholic scholars in the 13th century, it is only in 19th century that a dramatical increase took place on this subject. The mystery of the Cathars has undergone significant changes over the years and allowed for different ideological point of views to prevail at various periods. Cathars' Manichaean origin was perceived as the dominant view for many years in Cathar studies. This perspective, which we call the traditional view, claims that the dualist doctrine, which started with Manichaeism, reached the Cathars of Northern Italy and Southern France through the Paulicians in Anatolia in the 9th century and the Bogomils in the Balkans in the 10th century. This view seems to have been abandoned after the 1950s. Recently, a new trend, known as the "skeptic" view, has emerged whose supporters speculate that the Cathars may have never existed in history and could be an imaginary enemy invented by the Catholics. Contemporary historians of Cathars are divided into two: "traditional" and "skeptic." The purpose of this article is to propose a new category, "the contemporary view," which questions the Eastern connections of the Cathars on the one hand and criticizes the "skeptical view" on the other by considering the sufficiency of these two categories and the points on which historians agree and disagree.

Key Words: Cathars, Christian Heresy, Bogomils, Paulicians, Dualism, Cathar historiography.

\section{Giriş}

Hıristiyanlık tarihinde 1054 sonrasından XVI. yüzyılda Martin Luther'in Protestanlığına kadar Katolik Kilisesinden koparak mezhepleşmeyi gerçekleştirebilen bir akımın görülmediği bilinmektedir. Ancak bu durum zaman zaman ortaya çıkan muhalif grupların daha ziyade siyasi açıdan "ana akım" kabul edilebileceğimiz Katolik Kilisesi'nden ayrılabilecek düzeyde başarılı olamamalarıyla ilintilidir. ${ }^{1}$ Söz konusu gruplardan biri Katarlar ismiyle tanınan XII. ve

1 Çalışmamızda ana akım ifadesinin, tıpkı heresi kavramı gibi bir taraf ifade etmesi sebebiyle, tırnak içinde kullanılması uygun görülmüştür. 
Köken Tartışmaları Ekseninde Katarlara Dair Tarih Yazımındaki Güncel Paradiơma... XIII. yüzyılda Güney Fransa'da (Languedoc) yaşayan muhalif harekettir. Bu "heretik" hareket, Hıristiyan olduklarını ifade etmelerine karşın dönemin Papası III. Innocent'in (ö. 1216) deyimiyle “Müslümanlardan daha tehlikeli" 2 görüldüklerinden, üzerlerine bir Haçlı Seferi düzenlemiştir. On yıllar süren Albi Haçıı Seferleri, Katarları iyice zayıflatmış ancak yine de daha sonra tamamen ortadan kald1rılmaları için Engizisyon Mahkemeleri kurulmuştur. Böylelikle söz konusu muhalif hareket tamamen tarih sahnesinden silinmiştir.

Gerek yaşanan soykırımların şiddeti gerekse Katarlara ait kaynakların günümüzde mevcut olmamasının yarattığı "bilinmezlik" ve "gizem" dünya üzerinde pek çok popüler tarih yazıcısı ve akademisyenin ilgisini çekmektedir. Ancak tam da bu "bilinmezlik" uzun yıllar Katarlara dair tarih yazımının subjektifliğin de ötesinde, bilimsel bir dayanak gözetilmeksizin tamamen ideolojik bakış ve dini arka planların ön plana alınarak okunmasına imkân tanımış gibi görünmektedir. Bu tür yaklaşımlarda, deyim yerindeyse, Katarlar nasıl anlaşılmak istendiyse öyle yorumlandığı anlaşılıyor.

Katarlarla ilgili tarih yazımının yüzyıllar içerisinde farklı aşamalardan geçtiğini söyleyebiliriz. XIII. yüzyılda reddiyeler, vaazlar ve Albi Haçlı Seferi gibi önemli olayları konu alan kronikler, Engizisyon kayıtları gibi dokümanlarla Katarlara dair tarih yazım süreci başlamıştır. Ancak tahmin edileceği üzere bu kaynaklar -Katarların düşmanları olan Katolik otoritelerince yazılması sebebiyle- çoğunlukla taraflıdır. XVI. yüzyılda Protestanlığın doğuşuyla birlikte Katolik-Protestan çatışmasında Katarlar tarihinin tümüyle farklı sayılabilecek bakış açılarıyla bir çatışma malzemesi haline geldiğini görmekteyiz. Bu konunun, takip eden yüzyıllarda ise Fransa'nın

2 III. Innocent, Albi Haçlı Seferi çağrısında şunları söylemiştir: “Ey İsa'nın askerleri, ileri! İleri ey Hiristiyan ordusunun cesur erleri! Kutsal Kilise'nin evrensel 1stırap çığlığı sizi uyandırsın! Dinin hamiyeti Tanrıya karşı işlenen bu korkunç suçun intikamı için size ilham versin! Tanrı size ne vahyettiği şekliyle bu hain heresinin köklerini kurutun! Heretiklere Müslümanlara saldırdığınızdan daha pervasızca, şiddetle saldırın, çünkü onlardan daha kötüler. Walker Reid Cosgrove, Clergy and Crusade: The Church in Southern France and the Albigensian Crusade (Saint Louis Univerity, 2011), 1. Buradaki with a strong arm and stretched out arm ifadesi Mezmurlar'dan alınmıştır. Bk. Mezmurlar, 136:12. 
milliyetçi tarih yazımlarında ${ }^{3}$ kullanıldığına, "mazlum" statülerinden dolayı Marksist okumalara ${ }^{4}$ konu olduklarına, Orta Çağ “heretiklerinin" kadınlara olan müspet yaklaşımlarından dolay ${ }^{5}$ kadın çalışmalarında ${ }^{6}$ yer aldıklarına şahit olmaktayız.

Katarların tarihine dair ideolojik bakış açılarının ele alınması, konunun vuzuha kavuşmasına yardımcı olacağında şüphe olmamasına karşın bu çalışmanın sınırlarını aşmaktadır. Bu bağlamda, öncelikle Katarlara dair bazı çalışmalarda yöntem olarak takip edilen ancak Katarlara dair günümüz akademik yazınının değişen paradigmasında artık çok fazla rağbet görmediğini söyleyebileceğimiz, çalışmamızda geleneksel ${ }^{7}$ olarak tanımladığımız yaklaşım açılanacaktır. Daha sonra günümüz çalışmalarında "geleneksel" olarak anılan ancak bizim güncel görüş olarak tarif edeceğimiz paradigmaya yer verilecektir. Sonrasında en yeni yaklaşım olan şüpheci görüş incelenecektir. Tartışmada tarihçilerin ayrıştıkları

3 Augustine Thierry ve Jules Michelet gibi tarihçiler modern Fransız demokrasi geleneğinin ve Fransa'da ulus inşasının siyasi meşruiyetin temelinin Güney Fransa'da olduğunu düşünmektedirler. Bu durum Albi Seferinin sonuçları arasında da kaydedilmektedir. Ancak bu anlatıda Katarlar kahramanlaştırılarak XIII. yüzyıl Oksitanya'sı (Languedoc) demokrasi, hoşgörü ve özgürlük toplumu olarak kabul edilir. Meşhur milliyetçi Protestan vaiz Peyrat, Katarların kahraman şehitler olduğunu ve Montsegur kalesinin bir özgürlük, demokrasi ve hakikat anitı olduğunu belirtir. Detaylar için bk. Napoléon Peyrat, Histoire des Albigeois, c. 5 (Paris: G. Fischbacher, 1882).

4 Marksist Katarlar okumasında Katolik-Katar çatışmasının dini çatışma kisvesinde bir sınıf çatışması oladuğu kabul edilir. Karl Kautsky, G. Koch, Milorad Popowitsch, Gioacchino Volpe, Luigi Zanoni, Antonino de Stefano gibi düşünürler Katarların modern sosyalizmin öncüleri olduklarını iddia etmektedirler. Katarlar onlara göre dışlanmış sınıfların şikayetlerini dini muhalefet yoluyla ifade etmişlerdir.

5 Katarlarda kadınlar da din adamı sınıfına dahil edildiği bilinmektedir.

62001 yilında Vanderbilt Üniversitesi'nde yapılan “Medieval Heresies and Women's Freedom" isimli basılmamış doktora tezi, John Arnold'ın "Heresy and Gender in the Middle Ages" makalesi örnek gösterilebilir. Bunun yanında Anne Brenon da Doat koleksiyonundan getirdiği delillerle Katarlar hareketinde kadınların çok aktif olduklarının altını çizer.

7 Bu tanıma "geleneksel" ismini vermemiz geleneksel olanın ancak terkedilmiş bir düşünce olabileceği fikrinden ziyade, bu görüşün XIII. yüzyıla kadar dayanan uzun bir geçmişinin ve geleneğinin olması ve bunun yanında günümüz çalışmalarının "şüpheci" yaklaşıma dahil olmayan kısmının bu düşünceyle tam anlamıyla aynı çizgide bulunmadığını ifade etmeyi amaçlamaktadır. 
Köken Tartışmaları Ekseninde Katarlara Dair Tarih Yazımındaki Güncel Paradiogma... ve mutabık kaldıkları noktalar yorumlanarak açıklanacaktır. Böylelikle Türkiye'deki Katarlar çalışmalarını güncellemek ve günümüz tartışmalarına da mütevazı bir katkı sunmak amaçlanmaktadır.

Geleneksel görüşe geçmeden önce şu noktayı vurgulamak gerekebilir: Günümüz çalışmaları septik ve geleneksel olarak ikiye ayrılmaktadır. Bu çalışmada bir de güncel görüş eklendiği için bizim geleneksel tanımımız literatürde geleneksel olarak tanımlanan düşünceyle aynı değildir. Biz burada Maniheist kökeni kabul eden yahut Maniheist kökeni kabul etmese bile 'silsile teorisi/jeneolojik teori' dediğimiz Anadolu'da Pavlikenlerle (Paulicians) başlayan, yüzyıllar boyunca zaman zaman çeşitli coğrafyalarda gün yüzüne çıkan düalist düşüncenin Katarlara kadar ulaştığını savunan yaklaşımı kastetmekteyiz. Dolayısıyla bu çalışmada -diğer tarihçilerin tanımladığı gibi- şüpheci olmayan tarihçilerin tamamını gelenekselci olarak nitelendirmeyeceğiz. Bunun yanında çalışmamızda bu görüşleri iki kategoriye sıkıştırmanın çok isabetli olmadığını, ara kategorilerin de değerlendirmeye dâhil edilmesi gerektiğini belirtmek istiyoruz. Burada geleneksel yaklaşıma sahip, önemli olduğunu düşündüğümüz bazı tarihçilerin kanaatlerini kendi ifadelerine dayanarak aktarmaya çalışacağız.

\section{Geleneksel Görüş}

1950 öncesi Katarlar üzerine yapılan çalışmalarında yaygın olan düşünce, Katarların Maniheist kökenli olduğu fikrini savunan geleneksel görüştür. Konuyla ilgili literatürün yaygınlaşmasında Steven Runciman'ın etkili olduğu söylenebilir. Runciman'ın, Medieval Manichee $^{8}$ isimli eseri uzun bir süre Katarlara dair çalışmalar yapan araştırmacıların bakış açılarını şekillendirmiştir. Arno Borst Die Katharer'ini, Obolensky The Bogomils'ini, Söderberg La Religion des Cat-

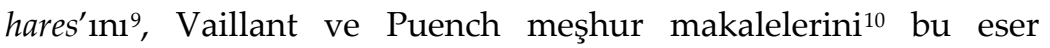
sonrasında kaleme almışlardır.

8 Steven Runciman, The Medieval Manichee: A Study for the Christian Dualist Heresy (Cambridge: Cambridge University Press, 1982).

$9 \quad$ Hans Söderberg, La Religion des Cathares (Almqvist \& Wiksell, 1949).

10 Puech, H. \& A. Vaillant, "Le Traité Contre les Bogomiles de Cosmas le Prétre: Traduction et étude", Travaux publiés par l'Institut d'Études Slaves, XXI (Paris: 1945). 
Runciman, kitabının başında "Orta Çağ Maniheizmi" ifadesini Orta Çağ Katolik Kilisesi yazarlarının ${ }^{11}$ bütün "düalistler" için kullandığını, bu ifadeyi gören tarihçilerin konuya temkinli yaklaşmaları gerektiğini söyler. ${ }^{12}$ Dolayısıyla Runciman geleneksel fikrin eleştirilme sebeplerinden birini baştan kabul etmiştir. Ancak ilginç bir şekilde bu eleştiri Runciman'1 geleneksel (jeneolojik teori/silsile teorisi) düşünceyi savunmaktan alıkoymaz. Runciman bir heretik grubu tarif etmenin kökenini bulmaktan her zaman daha kolay olduğunu ifade eder. Zira ona, göre heretikler, hep daha önceki bir geleneği yanlış anlamışlardır. ${ }^{13} \mathrm{Bu}$ sebeple Pavlikenleri anlatırken hangi erken dönem heresi (heresy) geleneğine isnat edileceğinin belli olmadığını belirtir. Ancak daha sonra Pavlikenlerin Gnostiklerin düalist geleneğini takip ettiklerini dile getirir. ${ }^{14}$ Runciman, Ermenistan'dan Anadolu'ya, oradan İmparatorluk şehrine, oradan Balkanlara IX. yüzyılda heresinin yayılması için uygun bir ortam olduğunu belirterek aslında klasik geleneksel düşünce haritasını çizmiş olur. ${ }^{15}$ $\mathrm{O}$, kitap boyunca tüm gelenekleri birbirine bağlar, bu geleneklerin zaman içerisinde çeşitli bölgelerde aldıkları yerel isimleri anlamları ile birlikte uzunca sıralar. ${ }^{16} \mathrm{Bu}$ diziliş dahi bütün grupları tek bir grup olarak gördüğünü kanıtlamaya yetebilir.

1950 sonrası jeneolojik görüşü takip eden nadir tarihçilerden biri olan Obolensky, Maniheizmin kadim bir gelenek olarak Bogomiller ve Katarlar aracılığıyla Avrupa'da devam ettiğini savunur. Ona göre Maniheizm Avrupa'ya iki büyük dalga ile girmiştir: İlki, III.-VII. yüzyıllar arasında, Suriye, Anadolu, Filistin'in güneyinden (Judaea) Mısır'a, Kuzey Afrika, İspanya, Güney Galya (Gaul) ve İtalya olmak üzere tüm Akdeniz coğrafyasını içine alarak Roma ve Bizans'a ulaşmıştır. Obolensky'nin pek çok yönden Maniheizmin

11 Schönau'lu Eckbert, Bernard Gui gibi yazarları kastetmektedir.

12 Steven Runciman, Medieval Manichee, 17.

13 Runciman, Medieval Manichee, 59.

14 Runciman, Medieval Manichee 62.

15 Ayrıntılı bilgi için bk. Runciman, Medieval Manichee, 63.

16 Bogomiller, Katarlar, Cathari, Kathari, Ketzer, Patarenler, Patareni, Patarini, Pavlikenler, Publicani, Poplicani, Albigenler, Albigeois, Albegenses, Phundaitler, Babuni gibi. Ayrıntılı bilgi için bk. Runciman, Medieval Manichee, 184-185. 
Köken Tartışmaları Ekseninde Katarlara Dair Tarih Yazımındaki Güncel Paradiogma... değişime uğramış hali olan, "Neo-Maniheizm"17 dediği ikinci dalgaysa, IX.-XIV. yüzyıllar arasında, Karadeniz'den Atlantik ve Ren nehrine kadar Orta Avrupa'nın güneyini tamamen istila etmiştir. ${ }^{18}$ Obolensky, Maniheizm'in varlığını sürdürebilme başarısının, Hıristiyanlığa kolayca adapte olabilmesinden kaynaklandığını belirtir. ${ }^{19}$

L'Abbe C. Douais, “Ne Afrika'nın Maniheistleri ne İspanya'nın Priscillianistleri ne Anadolu'nun Pavlikenleri ne Bulgaristan'in Bogomilleri ne İtalya'nın Patarenleri ne de Almanya'nın Katarları bize kendilerine yabancı bir dini takip ediyor gibi gelmemektedir" 20 diyerek bütün grupların düalist ve birbirinin devamı olduklarını anlatmaya çalışmaktadır. Douais, Obolensky gibi farklı "heresi" gruplarını Maniheizmin safhaları olarak değerlendirir. ${ }^{21}$ Ona göre, XII. yüzyıl Fransa toplumunun dini-ahlaki durumu Katarların hızla yayılmasını sağlamıştır. Katarlar böylelikle Güney'deki siyasal gücü ele geçirecek düzeye gelmişlerdir. ${ }^{22}$ Bununla birlikte Douais'in XIII. yüzyılın Kilise yazarlarının “Katarların” öğretileriyle Maniheist öğretinin farklılıklarından çok, benzerliklerini görüp dile getirdiklerini söylemesi, bunun onların mahiyetini anlayabilmek için gayet yeterli olduğunu ifade etmesi dikkate değerdir.

17 Obolensky çalışmasının bu bölümünde "Neo-Maniheizm olarak bilinen" ifadesini kullanmıştır. Bu terimi ilk defa meşhur XI. yy reddiyecisi Ademar kullanmıştır.

18 Dimitri Obolensky, The Bogomils: A Study in Balkan Neo-Manicheism, 2. bask1, (Twickenham: Cambridge University Press, 1972), 8.

19 Çalışmamızın sınırları sebebiyle Obolensky'nin düşüncelerinin tamamına yer vermek mümkün değildir. Detaylı bilgi için Obolensky'nin The Bogomils isimli eserine müracaat edilebilir.

$20 \quad$ L'Abbe C. Douais, Les Albigeois Leurs Origenes Action de L'eglise Au XIIe Siécle, 1. baskı (Paris: Librarie Academique, 1879), 3-4.

21 İlk safha, III. ve V. yüzyıllarda imparatorluk ve papalıkla mücadele süresi, ikincisi, Tuna nehrinin aşağısında bulundukları süre, üçüncüsü de VII. yüzyıla kadar geçen zaman dilimini kapsamaktadır. Ona göre bu son zaman diliminde Maniheizm, İmparatorluk hukukunun şiddetinden kaçarak mezhepleşmiştir. Douais için en önemli safha, Maniheizm'in üçüncü ve dördüncü safhalarıdır: VII. yüzyıldaki Pavlikenler ve X. yüzyıldaki Bogomiller. X. yüzyıl itibariyle, Bogomiller, Bulgaristan'da, Balkanlar'dan Slav ülkelerine ve Yunanistan'a yayıldıkları dördüncü bir Maniheizm biçimi olarak gelişmişti. Ona göre XI. yüzyılda Maniheizm, en başarılı safhasına girmiştir. Öte yandan Douais, Pavlikenlerin sadece isim olarak Samosatlı Pavlus'la ilişkili olduğunu, gerçekte Maniheizmin doğrudan varisleri olduğunu savunur.

22 Douais, Les Albigeois Leurs Origenes, 2. 
Geleneksel görüşü savunan tarihçilerden biri de Arno Borst'tur ${ }^{23}$. Borst'a göre Maniheizm'den gelen düalizm Batıya sirayet ettiği gibi Avrupa'nın dini atmosferini tümüyle değiştirmiştir. Borst, düalizmin süreç içerisinde tam bir "heresi" kıvamına geldiğini belirtir. Borst'a göre bu rafizî hareketler, gnostik Maniheizmin en klasik ve en katı düalist haline gelmiş ve böylelikle Maniheizm dini, bir "Hristiyan dini heresisi" ne dönüşmüştür. ${ }^{24}$

Jeneolojik fikri benimseyen tarihçilerden bazıları "heretik" geleneklerin Maniheist kökenden geldiğini düşünmez. Bu bizim güncel görüş kategorisine dahil ettiğimiz düşünceye evrilirken uğranan bir aşama gibi düşünülebilir. Örneğin Söderberg 25 jeneoloji düşüncesini savunsa da Maniheizmin Batı heresisinin kökeni olduğu fikrini kabul etmez. ${ }^{26}$ Morghen, Schmitd ve Söderberg Maniheist kökeni reddederek güncel görüşe geçiş konusunda öncülük etmişlerdir. Geleneksel yaklaşımı savunan meşhur tarihçilerden Dondaine $^{27}$, önceleri geleneksel düşünceyi savunurken daha sonra güncel paradigmayı benimsemiştir, bunda Morghen'la girdikleri tartışmanın etkili olduğu söylenebilir. Dondaine önceleri “Oksitan ${ }^{28}(\mathrm{Occi}-$ tan) Katarları, Bogomillerin oğullarıydı, Bogomiller de

23 Ayrıca Borst Katarlar hakkında 1950 öncesindeki ideolojik okumaları "Kaynakların ve Araştırmacıların Aynasında Katarlar" bölümünde ilk işaret eden kişi olması yönüyle de önemlidir. Lucy J. Sacville, Heresy and Heretics of the Thirteenth Century: The Textual Representations (York: York Medieval Press, 2011), 2 (aktaran A. Borst, Die Katharer, Monumenta Germaniae Historica Schriften, XII (Stuttgart: 1953), 1-58. Borst, Die Katharer, 63. Söderberg, La Religion des Cathares isimli çalışmasında, Bizans ve Batı dünyasındaki Hıristiyan düalizminin doğasını inceler.

26 Södenberg, Maniheizmin Batıda V. yüzyıl, Bizans'ta ise VI. yüzyıldan sonra yok olduğunun altını çizer. Düalizmin Doğuda IX. ve X. yüzyılda tekrar ortaya çıktığına işaret eden Södenberg'e göre Bogomiller ve Pavlikenler Batıda dini muhalefetin doğasını şekillendiren önemli gruplardır. Yine Södenberg'e göre "Katarlar" Bogomil hareketinin bir neticesidir. Bunun da ötesinde, ona göre XI. yüzyılın başında heretikler 'certaines doctines cathares'i benimsemişlerdi. Söz konusu heretikler, XI. yüzyıl' da Toulouse, Orléans, Chalon-sur Marne, Reims, Monforte ve Artois'te görülmüşler ve böylelikle XII. yüzyıldaki Batı ve Doğu düalizmi irtibatının kurulmasını sağlamışlardır.

27 Dondaine'in birçok reddiye, vaaz ve engizisyon metni üzerine yaptığı pek çok çalışması takdire şayandır. Buradan hareketle Schmidt, Dondaine, Douais gibi isimlerin Orta Çağ heresisi çalışmalarına yaptıkları en büyük katkının Latince pek çok Katar reddiyesini literatüre kazandırmaları olduğunu söyleyebiliriz. Güney Fransa'yı tanımlamak için kullanılan terimlerden biridir. Bölgede kullanılan dilde 'evet' anlamına gelen 'Oc' kelimesinden türetildiği söylenir. 
Köken Tartışmaları Ekseninde Katarlara Dair Tarih Yazımındaki Güncel Paradiogma... Maniheistlerin varisleriydi. ${ }^{29 "}$ derken, daha sonra, XII. yüzyıla kadar Batı' da "Katarizm" in bulunmadığını belirtmektedir. ${ }^{30}$

\section{Maniheist Köken Problemi ${ }^{31}$}

Katarların Maniheist kökenli olmadıklarına dair en güçlü delil, bu iddianın tamamen Katolik kaynaklarından alınması, Katarların asla kendilerini Maniheizmin devamı olarak tanımlamamasıdır. Ayrıca Katolik kaynaklarındaki Maniheizm ifadesinin olumsuz bir niteleme olduğunu da akılda tutmak gerekmektedir. Katolik reddiyevaazlarında "heresi" ve "Maniheizm" sık sık birlikte kullanılmaktadır. R. I. Moore'un da işaret ettiği gibi Maniheizm'e yapılan referansların kaynağı Augustinus okumalarıdır. Özellikle Chabbenes'li Ademar'ın 1018'de Aquitaine'de "Maniheistlerin" ortaya çıtı̆̆ını kaydetmesinden itibaren batı heresisinin yabancı kaynaklı olduğu fikri genel bir kabul haline gelmiştir. ${ }^{32}$ Moore'a göre Ademar'ın "neo-Maniheizm" ifadesini kullanması okuyucusunu doğrudan Augustinus'a yönlendirmek demektir. Zira o dönemde Augustinus'un Maniheist ve heresi reddiyeleri Katoliklerce gayet iyi bilinmekteydi.

Katarların Maniheist kökenli olduğunu iddia etmek gayet kullanışlıdır. Augustinus hayatının dokuz yılını Maniheist olarak geçiren ve daha sonra Katolikliğe döndüğünde Maniheizm'e dolayısıyla "heretiklere" birçok reddiye kaleme almıştır. Bunun yanı sıra Augustinus'un Hıristiyan dünyasındaki etki sahası ve "Adil/Haklı Savaş" teorisi akılda tutulmalıdır. Zira Augustinus okumaları vasıtasıyla Katarları Maniheizm'e bağlamak, heresi hakkındaki bütün tanım ve kanaatlerin onları da kapsamasını kolaylaştıracaktır. Böylelikle onlara uygulanan şiddetin nasıl meşrulaştırılabildiği de kolaylıkla anlaşılabilir. Burada bizi ilgilendiren en önemli husus,

29 Jeffrey Russell, “Interpretations of the Origins of Medieval Heresy", Medieval Studies 25/2 (1963): 36.

30 Russell, "Interpretations of the Origins of Medieval Heresy" 48, Dondaine, "L'hiérarchie Cathare en Italie".

31 Geleneksel görüşten kopuşlar en başta Maniheist kökenin reddi ile başlamıştır. Maniheist köken tartışmasına burada yer vermemizin sebebi bu kopuşu anlamaya çalışmak ve Katarlara dair tarih yazımındaki lineer seyri takip etmektir.

32 R. I. Moore, "The Origin of Medieval Heresy", History 55/183 (1970): 21. Ayrica Moore aynı eserde Orta Çağa ait kroniklerdeki bilgiler, manastırlara ait kütüphanelerdeki Orta Çağ otoritelerinin yazdığı eserlerden beslenen günümüz bilgileriyle kolaylıkla karıştırılabildiğini aktarmaktadır. 
"Maniheizmin" bir etiket olarak kullanıldığı net bir şekilde bilinirken, Orta Çağ Avrupası heresi tarihini "Maniheizm tarihi”ymiş gibi okumanın ne derece doğru olduğu meselesidir. Bu bağlamda geleneksel görüşü benimsemek, aslında hemen hemen Orta Çağda "heretiklere" yazılan reddiyeler ve kroniklerle aynı tarafta durmak, dolayısıyla objektif bir yaklaşımdan uzak olmak anlamına gelmektedir. Bu yaklaşım hususunda günümüz tarihçilerinden hem "geleneksel" (yani güncel) hem de şüpheci düşünceyi savunan nerdeyse bütün tarihçilerin ittifak ettiği söylenebilir. Güncel görüşe dahil ettiğimiz Janet ve Bernard Hamilton, Maniheistler düalisttir ancak $\mathrm{H}_{-}-$ ristiyan değildirler; dolayısıyla Hristiyan olduğunu iddia eden grupların Maniheizm'e dayandırılamayacağını belirtirler. ${ }^{33} \mathrm{Bu}$ konudaki ikinci argümanları, Hıristiyanlığın, kendisiyle hemen hemen aynı dönemde gelişen Gnostisizm'in kozmolojisiyle ortak noktalarının bulunmasıdır. Öte yandan, XI. yüzyıldan sonra Bizans dünyasında varlığını sürdüren organize Gnostik grupların olmadığı konusunda elimizde yeterli kanıt bulunmadığını iddia ederler. ${ }^{34} \mathrm{Bu}-$ nun yanında Hamilton'lar Orta Çağdaki Hıristiyan düalistlerin Gnostiklerin devamı olmadıklarını, son Hıristiyan düalizmi dönemine kadar kalabilmiş son Gnostiklerin Markionistler olduğunu belirtmektedir. ${ }^{35}$

\section{Paradigma Değişikliği: Güncel ve Septik Görüşü}

Güncel paradigma değişikliğinin icat teorisiyle (theory of invention) gerçekleştiği düşünülmektedir ${ }^{36}$. Septik görüşü savunan akademisyenler: "Katarlar Katoliklerin zihninde var ettikleri hayali bir düşman miydı?" sorusundan hareketle Katarlara dair tarih yazımına önemli bir katkı sunmuşlardır. Bu katkı, her ne kadar marjinal gibi görünse de Katarlar çalışmalarına bir canlılık getirmiş, bazı konular üzerinde tekrar düşünülmesini sağlamıştır.

Günümüzde, Katarlar sahasında çalışan tarihçiler genelde gelenekselciler (traditionalists) ve septikler(skeptics) olmak üzere ikiye ayrılsa da bize göre, geleneksel düşünce artık geçerliliğini yitirmiş

33 Janet \& Bernard Hamilton ve Yuri Stayenov, Bizans Döneminde (650-1405) Hiristiyan Düalist Heretikler, çev: Leyla Kuzucular (Yurt Kitap Yayın, 2010), 35-36. Janet, Bernard Hamilton ve Yuri Stoyanov, Christian Dualist heresies in the Byzantine World c. 650-1450, Selected Sources (Manchester University Press, 2013).

34 Hamilton, Hristiyan Düalist Heretikler, 37.

35 Hamilton, Hristiyan Düalist Heretikler, 38.

36 İcat teorisi ayrı bir başlık altında ilerleyen sayfalarda incelenmektedir. 
Köken Tartışmaları Ekseninde Katarlara Dair Tarih Yazımındaki Güncel Paradiogma... görünmektedir. Dolayısıyla günümüzde Maniheist kökeni ve silsile teorisini savunan akademisyenler yok denecek kadar azdır. Biz bu sebeple daha açıklayıcı bir ayrım için en azından bir kategori daha eklenmesi gerektiği kanaatindeyiz. Zira günümüzde "geleneksel" olarak tanımlanan grup homojen bir grup değildir. Bu bağlamda biz septik görüşü icat teorisi, terim tartışması, kısmen Bogomil-Katar bağlantısı gibi konularda eleştiren, ancak geleneksel düşüncede var olan Maniheizm kökeni, silsile teorisi/jeneolojik teoriyi kabul etmeyen akademisyenlerin "güncel görüş" (contamprary view) olarak farklı bir grupta değerlendirilmesini önermekteyiz.

Güncel görüşü savunan tarihçilerin birçoğunu dahil edebileceğimiz, Peter Biller'ın öncülük ettiği, York ekolü diyebileceğimiz yaklaşım Katarların engizisyon kayıtlarındaki aile şecereleri, meslekleri sosyal ağları gibi konular üzerinden incelenmesini öngörmektedir. John Arnold, Lucy Sacville, Rebecca Rist, Claire Taylor gibi Katarları çalışan önemli bilim insanlarını yetiştiren ekol, Doat projesi ${ }^{37}$ kapsamında doktora projeleri ve akademik yayınlarla tanınmaktadır. Septik görüşün temelini icat teorisinden aldığı söylenebilir. Güncel görüşte, Katarların teriminin kullanılmasında bir sakınca görülmez; dikkatli kullanıldığı takdirde Engizisyon kayıtlarının kullanılabileceği düşünülür. Söz konusu tarihçiler elbette Katarların Maniheizm kökenini reddeder, Doğu kökenlerini yani silsile/jeneoloji teorisini kabul etmez. Ancak Andrew Roach, Bernard Hamilton, Yuri Stayenov'un içinde bulunduğu önemli bir kısmı Katarlar-Bogomiller bağlantısının mümkün olduğunu savunur.

37 University of York, Doat 21-24. (https://www.york.ac.uk/res/doat/project/. Son güncelleme: 31.12.2020). Projenin tam ismi 'The Genesis of Inquisition Procedures and the Truth-Claims of Inquisition Records: The Inquisition Registers of Languedoc, 1235-1244' dur. Ancak dile kolaylık sağlamak için 'Doat' olarak anılmaktadır. Doat isminin kaynağı ise, yıpranan ve çürümeye yüz tutan Engizisyon kayıtlarını XVII. yüzyılda yeniden tekrar eden ve günümüze kadar gelmelerini sağlayan John Doat'tır. Dolayısıyla Doat projesi, Paris'teki Bibliothéque Nationale de France'deki Doat koleksiyonundaki ciltlerin İngilizce'ye tercümesi faaliyetidir. Bu kayıtlar sayesinde dönemin Languedoc'unda yaşayan insanların hayatları hakkındaki bilgilere erişebilmek isteyen tarihçilere imkân sunabilmektedir. Proje, günümüzdeki birçok Orta Çağ heresiologunun hocası Peter Biller'ın Paris Milli Kütüphanesi'nde araştırmaları esnasında XXI. ve XXVI. ciltlerin önemli bilgileri içerdiğini fark edip araştırmacıları tercümeye teşvik etmesiyle başlamıştır. 
Bu bağlamda, septik tarihçilerin yaklaşımları, makalenin icat teorisi kısmında analiz edilerek ve terim tartısmalarında şüpheci ve güncel düşünceyi savunan tarihçilerin düşüncelerine yer verilerek, Bogomil-Katar bağlantısı kısmında daha çok güncel paradigma ön plana çıarılacaktır.

\section{IV. İcat Teorisi}

Güncel tartışmaların bel kemiği diyebileceğimiz ana tartışma, heresinin sonradan icat edildiği teorisi etrafında şekillenmektedir. ${ }^{38}$ Foucaultcu tarih düşüncesindeki dönüşümün heresi çalışmalarına bir yansıması olarak tanımlayabileceğimiz bu yaklaşım, 1990'larda belirmeye başlayan, Mark Pegg'in ve R. I. Moore'un başını çektiği şüphecilik akımıdır. $\mathrm{Bu}$ düşünürler şüphecilerin yanında revizyonalistler, radikal septikler, icatçılar, yapı-sökümcüler olarak da anılmaktadırlar. Foucault'nun iktidar kavramından hareketle Katarların zavallı kurbanlar gibi sunulmasının realiteyle ne düzeyde örtüştüğünü sorgulamaktadırlar. Yine engizisyoncuların "Katarlar"a yapıştırdığ "heretik" etiketi üzerine bu kadar eğilmelerini, bu motivasyonlarının bir sonucu olarak görmek mümkündür. "Katarlar, tarihçilerin bir illüzyonu, bir mit, XII. yüzyıl Güney Fransa'sında zulmeden toplumun ürettiği bir bostan korkuluğ ${ }^{39}$, Albi Haçlı Seferi ve Engizisyonun kendini gerçekleştiren kehaneti, bir icadıdır." demektedirler. Bu tarihçiler temel itibariyle Katarların gerçekten var olup olmadığını sorgulamaktadır.

Şüpheci görüşü savunan tarihçiler yalnızca Pegg ve R. I. Moore'dan ibaret değildir. Moore'un, 1999'da yayınlanan, Monique Zerner'ın editörlüğünü yaptığı Inventer l'hérésie? Discours polémiques et pouvoirs avant l'Inquisition isimli eserden etkilendiği söylenmektedir. Uwe Brunn'ın XII. yüzyılın ortalarında Rheinland'da heresi raporları üzerine yazdığı eseri, Hilbert Chiu'nun akademik teolojide

38 Günümüz kaynaklarında Katarlar çalışan tarihçiler gelenekselci ve şüpheci şeklinde ayrılmaktadır ve şüpheci olmayan bütün tarihçilerin çoğunlukla "gelenekselci" olduğu belirtilmektedir.

39 Kaynaklarda Straw man of a persecuting society şeklinde ifade edilmektedir. John Arberth, Contesting the Middle Ages: Debates that are Changing Our Narrative of Medieval History (Taylor \& Francis Group, 2018). 
Köken Tartışmaları Ekseninde Katarlara Dair Tarih Yazımındaki Güncel Paradiogma... düalizmin inşasıyla ilgili açıklamaları, Mark Pegg'in XIII. yüzyılın ortalarını konu alan çalışması bu gruptandır. ${ }^{40}$

Şüpheci kategorisine dahil edilen tarihçilerin hepsi aynı görüşte değillerdir. En radikal septiklerden kabul edilen Pegg'in düşünceleri incelendiğinde, Katarların bir Balkan heresisi olmadığı, zulmeden toplumun inşa ettiği bir topluluk ${ }^{41}$ olmadığı, dahası böyle bir fenomenin Orta Çağ' da tarihte hiç var olmadığı iddialarının öne çıktığ1 görülür. Ona göre, "Katarlar" yalnızca XIX. yüzyıl akademisyenlerinin bir icadıdır. ${ }^{42}$ Hatta Orta Çağ entelektüelleri heresiyi nasıl icat ettiyse, XIX. yüzyıl akademisyenleri aynı şekilde Katarları icat etmişlerdir. XIX. yüzyılda din çalışan akademisyenlerin genel çalışma prensiplerini doğru bulmamış olması onu bu kanaate sevk etmiştir. Pegg'e göre bu akademisyenler dinleri yalnızca soyut doktrinler, farklı tutumlar, hiç değişikliğe uğramamış temsiller gibi sunmuşlardır. Bunun sonucunda Katarlar araştırmacıların zihninde değişmez, sabit düalist bir öğretiden ibaret bir hareket olarak kalmaya mecbur bırakılmıştır. Halbuki ona göre, düalizm Katarların ayrılmaz bir parçası değildir. Bilakis Oksitan (occitan $\left.{ }^{43}\right)$ kültürü dinin çok önemli bir parçasıdır. Pegg'e göre 'İyi İnsanlar'a (Katarlar) atfedilen meziyetler, aslında Oksitan kültüründe bulunan nezaket ve kutsallı̆̆ın birer ifadesidir.

Pegg silsile/jeneoloji fikrini kıyasıya eleştirmektedir. Ona göre XIX. yüzyıl akademisyenleri, adeta yüzyıllar boyunca bir sürü farklı toplum ortaya çıkmamış, bu toplumlar zamanla hiç kaybolmamış, hiç coğrafi ve kültürel farkları olmamış ve tamamen aynılarmış gibi Katarları silsile/jeneoloji teorisiyle, Maniheizm'e kadar geriye götürerek düalist bir zincirle birbirine bağlamışlardır. Pegg bu argümanını güçlendirmek için Sör Thomas Browne'dan bir alıntı yapar ve onun meseleyi gayet veciz bir şekilde özetlediğini belirtir: "(Heretikler) Yazarları gibi yok olmadılar. Arathusa nehri gibilerdi. Bir yerde yok olsalar da başka bir yerde yine çıtılar". Dolayısıyla Pegg

\footnotetext{
40 Michael D. Barbezat, Burning Bodies: Communities, Eschatology, and the Punishment of Heresy in the Middle Ages (2018), 6.

41 "Construction of a Persecuting Society" şeklinde kavramsallaştırılan ifade kast edilmektedir.

42 Mark Gregory Pegg, "The Paradigm of Catharism; or, the Historians' Illusion," Cathars in Question, ed. Antonio Sennis (Boydell \& Brewer, 2016), 21.

43 Dönemin Güney Fransa'sında Oksitan dili (ok dili) konuşulmaktaydı. Bölge zaman zaman Oksitanya ve kültürü ve dili de Oksitan şekilde anılmaktaydı.
} 
özetlediğimiz sakıncalar sebebiyle Katarizm olmaksızın yeniden bir heresi tarihi yazılması gerektiğini ifade etmektedir. XIX. yüzyıl din çalışmalarındaki bakış açısının yalnızca tek bir metinden hareket ettiğini ${ }^{44}$ ancak buna mukabil artık tarihi ve antropolojik derinlikle ve daha geniş bakış açılarıyla konuya yaklaşılması gerektiğini savunmaktadır. Bunun yanında fikirlerin, toplumların birbiriyle örtüşmesi gerektiğini ifade etmektedir.

Pegg, şüpheci olmasına karşın, bazı noktalarda Moore'dan ayrılmaktadır. Bu noktalardan biri Moore'un meşhur "zulmeden toplumun inşası" teorisidir. "Gelenekselci"lerden kabul edilmesine rağmen, Claire Taylor dahi, Moore'un bu teorisini, heresinin anlaşılmasına büyük katkı sağladığını belirterek takdir etmiştir. ${ }^{45}$ Hatta, sırf Moore'un bu teorisini konuşmak üzere, Michigan'da bir Orta Çă̆ kongresi toplanmış, daha sonra söz konusu kongre bu teorinin ismiyle kitaplaştırılmıştır. ${ }^{46}$

R. I. Moore, Formation of Persequiting Societ'sinde zulüm gören toplulukların yalnızca heretikleri değil, geç dönem XI. yüzyıl sonrası Hıristiyan toplumunda dışlanan Yahudiler, Müslümanlar gibi "azınlıkları", cüzzamlı, vebalı gibi görünür sağlık sorunu yaşayan,

Pegg ayrica Encyclopedia Britanica'da Conybeare' in Maniheistlerin doğrudan torunları olduğu konusunda şüphesi olmadan yazdığı Cathars maddesinin de araştırmacılara ciddi bir tesiri olduğunu kaydeder. Söz konusu maddede heresi gruplarının zaman ve mekândan bağımsız olarak tamamı aynı heresi olarak algılandığını, uzun süren gizli diasporadan sonra X. ve XIV. yüzyıllarda Pavlikenler Bogomiller olarak gün yüzüne çıktıklarını, bu grupların düalist eğilimleri olan her heresi gibi ayrımcılı̆̆a maruz kaldıklarını söylediklerini aktarır. Bu maddeye göre Maniheistlerin ardılları olan Bogomiller sık sık İtalya'yı ziyaret etmektelerdi. Bu durum İtalya'daki Katarlarla bağlantı kurulduğunu ifade etmektedir. (s. 182). Albigensis maddesinde de (Paul Daniel Alphandéry) Conybeare'e göre daha dizginlenmiş bir tonda yazıldığından bahseder. Maniheistler göz ardı edildiğini ancak Bogomil ve Pavliken etkisinin net olarak kabul edildiğini aktarır. Albigenler (Katarlar)'in ilk Limousin'de 1012 ve 1020 civarında görüldügünü ve son olarak XI. yüzyılın ilk zamanlarında Toulouse'a göç ettikleri aktarılır. 80 yıl sonraki edisyonda da Encyclopedia of Religion'da aynı şekilde olduğunu belirtmiştir. Böylelikle bu yazarlar Pegg'e göre kendilerinden önceki yüzyılda Katarlar hakkında ve diğer bütün heretikler hakkında ne düşünüyorlarsa onu kendi çağlarına aktarmışlardır.

45 Claire Taylor, Heresy, Crusade and Inquisition in Medieval Quercy (York University Press, 2011), 17.

46 International Medieval Congress Kalamazoo, Michigan, R. I. Moore ve Michael Frasetto, Heresy and the Persecuting Society in the Middle Ages: Essays on the Work of R. I. Moore (Leiden: Brill, 2006). 
Köken Tartışmaları Ekseninde Katarlara Dair Tarih Yazımındaki Güncel Paradiơma... ancak dini bakımdan da cezalandırıldığı düşünülen insanları, eşcinseller gibi toplumun ahlaki açıdan doğru bulmayıp reddettiği kesimleri de kapsadığını iddia etmektedir. Bunun için Orta Çă̆ otoritelerinin kınanması gerektiğini belirten Moore, şunları aktarmaktadır: "Zulüm, siyasi nüfuz yarışında bir silah olarak başladı, galip gelenlerce toplum üzerindeki güçlerini pekiştirebilmek için bir araca dönüştürüldü. ${ }^{47}$ Moore, zulmün durup dururken ortaya çıkmadığını, yeni hedefler doğrultusunda baskının arttırılmadığını düşünmektedir. Ona göre, daha ziyade, heretiklerin tespit edilip toplumdan dışlanması, otoritenin meşrulaştırılması ve genişletmesine imkân tanımıştır. Merkezi güçlerin yükselişe geçmesi de bunu pekiştirmiştir. Moore'a göre, bu durumun ortaya çıkma sebebi, yeni çıkan eğitimli seçkinlerin, okullar vasıtasıyla fikirlerini yaymasıdır. Moore, bu eğitimli kesimin fikirlerini hem seküler yönetime hem de dini merkezileştirip bürokrasiyi oluşturmak suretiyle topluma dayattığını savunur. 48

Moore'un eserinin temel iddiası, prenslerin veya piskoposların kanaatlerinin, zamanla halk nezdinde heretikler, Yahudiler gibi ötekiler hakkında bir nefret duygusu oluşturulması, bununla zulmün kolay uygulanmasına zemin hazırlanmasıdır. ${ }^{49}$ Dolayısıyla bu grupların aslında gerçekten tehlike oluşturmadıkları, ancak bir tehdit algısı inşa edildikten sonra, bunun herkesçe kabul edilmesi sağlanıp zulmün bu şekilde meşrulaştırıldığı fikri savunulmaktadır.

Öte yandan, Orta Çağ heresi tarihi sahasındaki çalışmalarına yarım asırdır devam eden Moore, daha önce bizim güncel görüş olarak tanımladığımız bakış açısına sahipken, sonradan "septik" yaklaşıma katılmıştır. Moore, Georges Duby'nin tarihin değiştiğini söylemesi gibi, tarih biliminin ve tarihçinin de gelişmeye açık olması gerektiğini vurgular. Moore'a göre değişen ve gelişen yalnızca tarih ve tarihçi değildir. Ona göre Katarlar bağlamında XIII. yüzyılda yaşanan en büyük yanılgılardan biri heresinin aynı kaldığının zannedilmesidir. Moore bu yanılgıyı bilinçli bir farkındalık göstermediğimizde, istasyonda bulunduğumuz trenin değil de

47 R. I. Moore, The Formation of a Persecuting Society: Authority and Deviance in Western Europe, 950-1250 (Blackwell Publishing, 2009), 146.

48 Barbezat, Burnibg Bodies, 5.

49 Detaylı bilgi için bk. Moore, The Formation of a Persecuting Society. 
başka bir trenin hareket ettiğini zannetmemize benzetir. ${ }^{50}$ XIII. yüzyıl Kilisesi entelektüelerinin heresiyi daima sabit kaldığını zannedip XII. yüzyıldaki heresiyle aynı olduğunu düşünmeleri de bunun gibidir. Moore heresinin değiştiğini, geliştiğini savunur. Buradan hareketle, bizim ancak gözlerimizi bir noktada sabitlemediğimiz takdirde dünyanın bir akış içinde olduğunu anlayabileceğimizi belirtir. ${ }^{51}$

Öte yandan "gelenekselciler"den olarak bilinen Peter Biller, Moore'u ve bu değişimini The War kitabının değerlendirmesi üzerinden eleştirir. Örneğin Moore'un Katarlar tarihi hakkındaki görüşlerinin değişimi konusunda, uzmanı olduğu XI. yüzyıldan uzaklaşarak akademik olmayan, popüler bir yaklaşımla XII. ve XIII. yüzyıllara yönelmesini rahatça hareket edebileceği kendi sahasından uzaklaşması olarak değerlendirir. Bundan dolayı Biller'a göre Moore'un kullandığı kaynaklar yeterince güvenilir değildir. Bu sebeple Moore'un argümanlarının zayıfladığını düşünür.

Moore'un çok radikal bir değişimle şüpheci fikre geçtiğini belirten Biller, Katarizmin "yapılandırılmış" bir grup olduğu önerisini sunduğunu aktarır. Moore bu teoriyle Katarların "icat" edildiğini, bu icatta yerel Kilisenin, Kilise adamlarının sıkı sıkıya muhafaza ettikleri hayal güçlerinin ${ }^{52}$ ve 1230 yılı sonrasında Dominiken Engizisyoncuların yaratıcılığının etkili olduğunu belirtmektedir. Biller'ın Moore'a eleştirileri bunlarla sınırlı kalmaz; ayrıca belgelere yaklaŞımı da eleştirir. Biller'a göre Moore, bir taraftan belgelerin siyasi bağlamı, yazarların abartılı davranıp davranmadığıyla ve metnin sahte olup olmadiğıyla ilgilenirken, diğer taraftan metnin yazıldığı bağlamı değerlendirmeyi, bu bağlamı, metnin türü, dili ve şekliyle ilişkilendirmeyi ihmal etmektedir. Buradan hareketle Biller, Moore'un eleştirel yorum yaparken tek yönlü bir tutum sergilediğini savunur. Böylelikle, metnin varlı̆̆ını göz ardı eden ve değerini takdir etmeyen bir yaklaşım sergilediğini düşünür. Hatta bu konudaki eleştirisini keskinleştirerek Moore'un Toulouse'daki heresinin varlığıyla ilgili uzlaşma kararnamelerini değerlendirmesini ve süreç

50 Cathars in Question: A Responce to Pete Biller, http://rimoore.net/2016/11/13/cathars-in-question-a-response-to-pete-biller/ (Son güncelleme: 9 Aralık 2020).

51 Cathars in Question: A Responce to Pete Biller, http://rimoore.net/2016/11/13/cathars-in-question-a-response-to-pete-biller/ (Son güncelleme: 9 Aralık 2020).

52 Augustinus ve daha sonra XII. ve XIII. yüzyıllarda yazılan reddiyeler kastedilmektedir. 
Köken Tartışmaları Ekseninde Katarlara Dair Tarih Yazımındaki Güncel Paradiogma... içerisinde ulaştığı neticeyi eleştirir. Ona göre Moore, Canterbury'li Gervase'nin 1177'de yazdığ bir mektuptan söz etmesini "niçin başka bir kaynakta değinilmemiş?” diyerek geçiştirmiştir. Biller, Moore'un eserin ilerleyen bölümlerinde söz konusu kaynağ1 "otantikse" diyerek itibarsızlaştırıp, nihayet son bölümde metnin sahte olduğu sonucuna vardığını söyler.

Moore'un en önemli iddialarından birisi, Katarlar kilisesinin XIII. yüzyıla kadar hiç fiziken görülmediği, dolayısıyla XIII. yüzyıl öncesinde Katarların bir fenomen olarak var olmadıkları düşüncesidir. Dolayısıyla bu kilisenin Doğu kökenlerinin tamamen bir mitten ibaret olduğunu belirtir. Hatta bu konuda Biller, Moore'un Bogomillerin hala konuşulmasını tahfif eden ifadesi konusunda, Moore'u yeterli delille izale etmemesi sebebiyle eleştirir. ${ }^{54}$ Diğer taraftan Moore, Biller'ın XII. yüzyılda organize olmuş bir düalist yapı olabilirdi düşüncesini zaten hiçbir zaman inkâr etmediğini söyleyerek kendisini savunur.

Şüpheci tarihçilerden Jean-Louis Biget, önce evanjelik amaçlarla yola çıkan dini muhalefetin("heresi"nin) giderek ruhbaniyet karşıtlı̆̆ına (anticlericalism), daha sonra da düalist bir heresiye dönüştüğünü iddia eder. Ancak Biget, bu muhalefetin, sadece entelektüel Kilise adamlarından oluşan seçkinlerin zihinlerinde var olduğunu ve halka bu şekilde lanse ettiklerini düşünmektedir. ${ }^{55}$ Yine şüpheci tarihçilerden Julien Théry-Astruc, Katarlara ait olduğu iddia edilen "düalist öğretinin" entelektüellerin hayal ürünlerinin topluma yansıtılması sonucunda ortaya çıtı̆̆ını, dolayısıyla Katarlarda düalizmin gerçekten var olmadığını iddia etmektedir. ${ }^{56}$

Moore'a göre, Uwe Brunn, XII. yüzyılda Rhineland'da Katarların görüldüğünü iddia eden "geleneksel” görüşe öldürücü darbeyi

\footnotetext{
53 Kötü ve İyi Tanrı, düalizm.

54 Peter Biller, "Goodbye to Cathars", Cathars in Question, ed. Antonio Sennis (Boydell \& Brewer, 2016), 288. (Text and Context in Early Popular Heresy, 2009'daki Leeds Medieval Congress)

55 Barbezat, Burning Bodies; Jean-Louis Biget, Hérésie et inquisition dans le Midi de la France (Paris: Picard, 2007), 107-115.

56 Julien Théry-Astruc, "The Heretical Dissidence of the 'Good Men' in the Albigeois (1276-1329)": Localism and Resistance to Roman Clericalism," Cathars in Question, ed. Antonio Sennis (Boydell \& Brewer, 2016), 81.
} 
vuran kişidir. ${ }^{57}$ Frankafon çalışmalarındaki -Katarların tarihi gerçekliğini sorgulayan- şüpheci yaklaşım Monique Zerner'ın Inventer l'hérésie? ${ }^{58}$ isimli eseri ile başlamıştır. Brunn, bu şüpheci kanadın yeni temsilcisidir. Brunn, terim tartışmalarında da şüpheci yaklaşımla aynı fikirdedir. Katar teriminin, Rheinland'da, XII. yüzyılda, özellikle Schönau'lu Eckbert'in diğer reddiyelerden öğrendiği kalıpları çeşitli muhalif grupları tarif etmek için kullanmasıyla ortaya çıktığ1 neticesine ulaşır. ${ }^{59}$ Brunn'a göre, bunun sebebi, Benedikten keşişi Eckbert'in, Augustine'in Maniheizm ve Katarlar kelimelerinin bir arada olduğu Kilise konseylerinden, rahiplik eğitiminde karşılaştı̆̆1 edebi kavramlardan bir türlü kendisini alamamasıdır. Netice itibariyle Brunn'un çalışması, Eckbert' in "Katarlarını" başka yerlerdeki diğer muhalif gruplarla ilişkilendirmek ve onların teolojisini Katar teolojisine uygulamaya çalışan modern bilimsel anlatılara meydan okumaktadır.

Pegg ve Brunn, heresi çalışmalarındaki historiografinin iki kanaldan geldiğini savunur. Birisi Orta Çağ yazarlarının varsayımları ve zihinleri oluşturdukları filtrelerden hareket eder. Diğeri heresi alanındaki modern bilimsel verilerle şekillenir.

\section{Terim Tartışması}

Orta Çağ Hıristiyan "heresisi" hakkındaki en güncel tartışmaların merkezinde, bu grupların Katolik kaynaklarıyla çalışılmasının nesnel olmaması yer alır. Bu sebeple bu grupları "heretik", "düalist", "Katar" gibi ifadelerle isimlendirmenin Katolik kaynakların etkisinde kalarak Kilise'nin tarafında yer almak anlamına geldiği düşünülmektedir. Dolayısıyla Katarlar terimi, "heretik", "heresi" terimleri gibi artık tartışmaya açık durumdadır. ${ }^{60}$ Bunun sebebi Cathari keli-

57 Moore, “Principles at Stake," s. 262.

58 Monique Zerner (ed), Inventer l'hérésie? Discours polémiques et pouvoirs avant l'inquisition (Nice: Centre d'Études Médiévales, 1998).

59 Burning Bodies'ten aktaran Uwe Brunn, Des contestataires aux "Cathares" Discours de réforme et propagande antihérétique dans les pays du Rhin et de la Meuse avant l'Inquisition (Paris: Institut d'Études Augustiniennes, 2006).

60 R. I. Moore ile gerek New Castle' da yüzyüze görüşmelerimizde gerekse e-posta üzerinden yazışmalarımızda "Katar" kelimesini çalışmalarımızda kullanmamız gerektiğini sıkı sıkı tembih etmesi ve böyle bir durumda bu yaklaşımdaki bir çalışmayı okuma konusunda bile isteksizlik gösterilebileceğini belirtmesi ilginçtir. Ancak yine bizzat derslerine katılıp doğrudan çalışmalarımıza katkı sağlayan Andrew Roach, Moore'la aynı fikirde değildir. Keza, Peter Biller ve talebeleri de aynı kanaattedir. 
Köken Tartışmaları Ekseninde Katarlara Dair Tarih Yazımındaki Güncel Paradiogma... mesini ilk defa meşhur Katar reddiyecisi Katolik Schönau'lu Eckbert'in, 1163'te Köln'deki "heretikleri” tanımlarken kullanmasıdır. Sonraki yıllarda Sermones Contra Catharos ismindeki reddiyesinde de aynı ifadeyi kullanmıştır. Söz konusu dini muhalefet grubu kendilerinden hiçbir zaman "Katar" şeklinde bahsetmemiş, kendilerini "İyi Hıristiyanlar", "İyi Kadınlar", "İyi Erkekler" olarak tanımlamışlardır. Dolayısıyla "Katar" teriminin reddiyelerdeki kullanımı, hatta cathar kelimesinin cat'den geldiği ve kediye taptıkları gibi iddialar da göz önünde bulundurulursa, aslında "Katarlar" kelimesinin bir aşağılama ifadesi olduğu rahatça anlaşılabilir. Bunun yanı sıra "heretik" tanımlamasının aşağılama içerdiği, bir ötekileştirme ifadesi olduğu ve "doksa"nın, yani doğrunun zıttını ifade ettiği ve netice itibariyle asla objektif olmadığı zaten açıktır. Ayrıca "Maniheist" ve bunu ima eden "düalist" terimleri de çok objektif görünmemektedir. Zira "maniac" kelimesinden türetildiği bilinen "Maniheist" terimi Orta Çağlarda bir aşağılama ifadesi olarak da kullanılmaktaydı. ${ }^{61}$. "Katarizm" kelimesini ilk olarak tartışmaya açanlardan birisi Corruption of Angels isimli eseriyle Mark Pegg'dir. ${ }^{62}$ Pegg'in bu konudaki temel iddiası, -yukarıda bahsettiğimiz Schönau'lu Ecbert'in reddiyesine referansla- Katar kelimesinin Katolikler tarafından kullanıldığı, hatta ilk defa bir reddiyede kullanıldığıdır. Pegg, ayrıca Katarların kendilerine Katar değil de erkeklerine "İyi Adam", kadınlarınaysa "İyi Kadın" dediklerini de hatırlatmaktadır. Bu tartışmaya 2012 yılında katılan R. I. Moore, The War on Heresy isimli çalışmasıyla Pegg'in tezine destek vermiştir. Daha sonra 2016 yılında yayınlanan ve "Katarlar" hakkındaki en güncel çalışma olan Cathars in Question ${ }^{1}$ isimli eserde, sahanın duayenlerinden Biller, kitapta kendisine ayrılan bölümde bu konuyu ele almış, söz konusu araştırmacıları epeyce eleştirmiştir. Biller, terimler hakkında takip edilen bir prensibin gerekliliğini vurgularken, aynı zamanda Pegg ve Moore'un Almanca literatürdeki eleştirel

61 Kelimenin köken itibariyle mania'dan geldiğine dair bk. C. T. Onions (ed), "Mania", The Oxford Dictionary of English Etymology (New York-Oxford: Clarendon Press, 1966), 551-552.

62 Mark Pegg, The Corruption of Angels: the Great Inquisition of 1245-1246 (Princeton University Press, 2009). Pegg, bu eserde ve "On Cathars, Albigenses or Good Men of Languedoc" isimli makalesinde "Katar" ve "Katarizm" kelimelerini ele almaktadır. 
yaklaşımları takip etmediklerini belirtmiştir. Daha sonra R. I. Moore, kendi sitesinde Peter Biller' in bu yazısina "Cathars in Question: a Response to Peter Biller" başlığıyla bir cevap vermiştir. ${ }^{63}$ Sonuç olarak "Katar" kelimesinin kullanımı halen tartışmalıdır.

\section{Bogomil-Katar Bağlantısı ve Düalizm Tartışması}

Katar- Bogomil bağlantısını daha çok güncel görüşü savunan tarihçiler kabul etmektedir. Bogomillerin ve Katarların katıldığı düşünülen St. Félix-de-Caramen konsili Bogomil-Katar bağlantısını savunan tarihçiler açısından kritik bir bağlantı noktası ve argümanları için bir delil niteliğindedir. Çünkü bu tarihçilere göre bu konsil Bogomillerin ve mutlak düalizmin Languedoc' a gelişi anlamına gelmektedir. St. Félix, Toulouse'un güneyinde, yani Languedoc bölgesinde bulunmaktadır. Bu toplantı, söz konusu tarihçilerce bir nevi Katarların ılımlı düalizmden mutlak düalizme geçme seremonisi gibi anlaşılmaktadır. Ancak bu konsilin çok da mühim olmadığını düşünen bazı tarihçiler de vardır ve Mark Pegg bunlardan birisidir. Pegg, bu konsilin gerçekten toplandığına dair delillerin ikna edecek kadar yeterli olmadığını savunur. ${ }^{64}$ Anne Brenon da konsilin eklesiyastik organizasyonlar açısından önemli olduğunu, ancak Katar doktrinleri açısından mühim olmadığına inanır. ${ }^{65}$

İtalyan Raffaello Morghen gibi diğer bazı tarihçiler, temel prensiplerini Bogomil öğretisinden alan, dolayısıyla birçok açıdan onlardan etkilenmeleri beklenen heretiklerin, düalizme açık bir referans vermemelerine dikkat çekmektedir. Hatta beklenen benzerliğin aksine, Katarların bazı inançları, Cosmas' ${ }^{66}{ }^{66}$ eserinde belirtilen Bogomil inançlarıyla kıyaslanamayacak düzeyde Bogomiller'den farklıdır. Morghen, Katarların tüm özelliklerinin dış etkilere ihtiyaç duyulmadan da anlaşılabileceğini ileri sürmektedir. Bunun da ötesinde Morghen'a göre Dondaine'in yaptığı analojilerde bazı sakıncalar da bulunmaktadır. ${ }^{67}$

Cathars in Question: A Responce to Pete Biller, http://rimoore.net/2016/11/13/cathars-in-question-a-response-to-pete-biller/ (Son güncelleme: 9 Aralık 2020). Mark Pegg, The Corruption of Angels.

65 Anne Bradford Townsend, The Cathars of Languedoc as Heretics: From the Perspectives of Five Contemporary Scholars (Basılmamış Doktora Tezi, Union Institute\&University Cincinnati, Ohio: 2007), 28-29.

66 Bogomiller hakkında birinci elden bilgi edinebildiğimiz bir kaynaktır.

67 R. I. Moore, The Birth of Popular Heresy, (London: Edward Arnold, 1975), 5-6; R. I. Moore, The Origins of European Dissent (Oxford: 1985), 8-20. 
Köken Tartışmaları Ekseninde Katarlara Dair Tarih Yazımındaki Güncel Paradiogma...

Günümüz tarihçilerinden Bogomil bağlantısını en çok savunan akademisyenlerden birinin Bernard Hamilton olduğu söylenebilir. Hamilton'a göre, aksini iddia eden tarihçilerin "Bogomillerin X. yüzyılda Batı Avrupa'da olduklarına dair kuvvetli bir delil yoktur" itirazları çok önemli değildir. Nitekim ona göre söz konusu dönemde Bizans İmparatorluğunda dahi Bogomilleri teşhis edebilmek ve onları Ortodoks keşişlerden ayırt edebilmek hiç de kolay bir iş değildir. Bu sebeple ona göre Bogomillerin Avrupa'da tanınamamış olmaları normaldir. Yine Hamilton, XI. yüzyılın ilk yarısında Batı Avrupa'da önemli sayıda Ortodoks keşişin var olduğunu, ancak eğer XI. yüzyılın ilk yarısında Bogomiller ve Batı Avrupa arasında gerçekten bir bağlantı vardıysa da bu bağlantının ne görünür düzeyde ne de uzun soluklu olmadığını belirtir. Öte yandan Hamilton, $1325^{\prime}$ te son Katar din adamlarının izlerinin Batı Avrupa'dan silinirken, Papa XII-. John, Bosnalı Stephen Katromanic'e kalabalık bir heretik grubunun bir araya gelip Bosna'ya göç ettiğini yazmıştır. Hamilton Papa'ya ulaşan bu bilginin doğru olması durumunda Bogomil ve Katar bağlarının son ana kadar devam ettiği sonucunun çıkarılabileceğini iddia etmektedir.

Batı Avrupa'ya düalizmin gelişine dair en kesin delil, geleneksel olarak 1167 yılında olduğu söylenen ancak daha büyük olasılıkla 1174 yılında gerçekleşen St. Félix-de-Caramen konsilidir. Her ne kadar bu toplantıyı bildiren belge muhtemelen bu tür birkaç toplantıyı bir araya getirse ve 1232 yılında yazılsa da Languedoc ve Güney Fransa'daki Katarizmin kökenleri ve doğası hakkında net bir kanıt sunmaktadır. Konsil, Kuzey Fransa, Albi ve Lombardiya'dan Katar piskoposlarının bir araya gelmesiyle birlikte, Carcassonne, Agen ve Toulouse'daki Katarlar kiliselerinin temsilcileriyle yapıldı ve başkanlığını Doğu misyoneri Papa Niquinta veya Constantinople Nicetas gerçekleştirdi. ${ }^{68}$

Malcolm Lambert gelenekselci olmayan, fakat Bogomil etkisini kabul eden tarihçiler arasındadır. Lambert Ademar'ın XI. yüzyılda heretikleri tasvir ederken Maniheizme benzettiğinin farkındadır. Onun Aquitaine' de Maniheistlerin ortaya çıtı̆̆ını iddia ettiğini be-

68 Michael Frasetto, Heretic Lives Frassetto, Heretic lives: Medieval Heresy from Bogomil and the Cathars to Wyclif and Hus (London: Profile Books, 2007), 76-78. 
lirtir. Evliliği, et yemeyi, vaftizi, haçı, "Kutsal" Kilisenin kurtarıcıllğını reddettiğini belirtir. ${ }^{69}$ Ayrıca Ademar'ın heretikler için Maniheist demekten çekinmediği yineler, bu konuda yalnız olmadığını belirtir. Landulf'un Montforte'taki grup için, Yukarı Lorrraine'deki gruplar için bir kronikçinin, Chalon-sur-Marne'nin Liege'li Wazo'ya yazdığı mektupta bölgesindeki heretiklerin Maninin Kutsal ruh olduğuna inandıklarını belirtir. Ancak Lambert'a göre bu kişilerin Maniyi duymuş olmaları pek muhtemel değildi. ${ }^{70}$ Dolayısıyla aslında Lambert geleneksel görüşü desteklemez ama heresi gruplarını XI. yüzyıldan itibaren incelemeye başlar. Ayrıca Katarların Bogomillerin mirasçısı olduğunu düşünmektedir.

Bernard Hamilton'ın radikal düalizmin Nicetas'ın ziyaretinden sonra benimsenmiş olduğunu kabul ettiğini ifade eder. Albi Haçlı Seferi bittiğinde Cascasson'lu Bartholomew'un Agen'de 1lımlı düalizmin güçlenmesi için çalıştığını ancak çok etkili olmadığını belirtmektedir. Anne Brenon'un Les Cathares isimli eserinde (s. 131-140) Languedoc'taki Katarların din adamlarının Nicetas sayesinde mutlak düalizme geçtikleri görüşünü reddettiklerini belirttiğini aktarır. Buna delil olarak da Brenon'un Raimon de Baimiac'in 1lımlı düalizmini gösterdiğini kaydeder. ${ }^{71}$ Katarların Bogomillerin mirasçısı olduğunu söyler. Bunu genellikle ibadet üzerinden delillendirir. İkisinin de haçı reddetmesi gibi mit ve doktrinlerinin birbirine geçmelerine rağmen, tamamen aynı iki grup olmadıklarını belirtir. ${ }^{72}$ Bunları yine consolomentum gibi bazı ibadetler üzerinden açıklar

\section{Sonuç}

Katarlar'a dair tarih yazımının en az Katarlar kadar enteresan ve anlaşılmayı bekleyen bir serüvene benzetilebilir. XIII. yüzyıldan başlayan ve XIX. yüzyıla kadar çeşitli dini, dini ve ideolojik arka planlara doğrudan maruz kalan bu tarih yazımının, günümüzde nispeten daha objektif yöntemlerle çalışılmaya başlandığını söylemek mümkündür.

Her ne kadar bazı çalışmalarda heretiklerin Maniheizm ve Doğu kökenli olduğu kesinmiş gibi kabul edilse de bu görüş artık

69 Malcolm Lambert, Medieval Heresy: Popular Movements from the Gregorian Reform to the Reformation (Oxford: Blackwell, 2002), 25.

$70 \quad$ Lambert, Medieval Heresy, 38.

71 Lambert, Medieval Heresy, 143.

72 Malcolm Lambert, The Cathars (Blackwell Publishing, 2007), 32. 
Köken Tartışmaları Ekseninde Katarlara Dair Tarih Yazımındaki Güncel Paradiơma... günümüzde çok takip edilmiyor gibi görünmektedir. Bunun yanında Katarlarla ilgili tarih yazımına son dönemdeki çalışmalara bakıldı̆̆ında keskin bir ayrım göze çarpmaktadır. Septik paradigmayı savunmayan bütün tarihçiler gelenekselci olarak nitelendirilmektedir. Ancak (i) jeneoloji düşüncesini savunan, (ii) Maniheist kökeni savunmayan, (iii) her ikisini de köken olarak kabul etmeyen ancak Bogomiller bağlantısının mümkün olduğunu düşünen ve (iv) böyle bir bağlantının olmadığını düşünenler gibi pek çok kategoriden söz edilebilir. Dolayısıyla bu çalışmada septik yaklaşıma karşı çıkan her tarihçinin aynı biçimde düşünmediği ve en azından bir kategorinin daha eklenmesinin daha uygun olabileceği düşünülmektedir. Burada ön görülen tasnife göre, 1950 öncesi savunulan Maniheist köken ve jeneoloji/silsile teorisi geleneksel yaklaşım, bu kökenleri kabul etmeyen ancak septik düşünceye önemli bazı noktalarda eleştiren tarihçiler güncel görüş olarak tanımlanmakta ve septik düşünce üçüncü bir kategori olarak kabul edilmektedir.

Çalışmadaki iddialardan bir diğeri şudur: Septik yaklaşım birçok konuda eleştirilse de Katarlar çalışmalarının tekrar gündeme alınması, geliştirilmesi açısından çok faydalı olmuştur. Güncel paradigmayı savunan tarihçiler septik tarihçileri eleştirse de Maniheist kökenin ve silsile teorisinin reddi, Katolik kaynaklarından elde edilen verilerin mutlak gerçeklik olarak alınmaması gibi pek çok konuda onlarla fikir birliği içerisindedirler.

Septik görüş “Katarlar” ismi dahil olmak üzere, "heresi”, “düalizm" gibi terimleri de tartışmaya açmıştır. Septik yaklaşımın "Katarlar gerçekten "heretik" bir hareket miydi yoksa Katolik Kilisesinin kendi tahayyülleri sonucunda kendinin var ettiği bir düşman kategorisi miydi?" sorusunu gündeme getirmesi ve dönemin siyasi ve sosyal yapısını anlatan kaynaklardan yeniden yapılandırma suretiyle bir tarih yazılması gerektiği fikri Katarlara dair çalışmalarda bir paradigma değişimine sebep olmuştur. Bu değişim yukarıda bahsettiğimiz neticeler sebebiyle elbette çok kıymetlidir. Dini ve siyasi muhalefetin getirdiği bir ötekileştirmenin varlığı da yadsınamaz. Ancak dini açıdan hiçbir farklılık yaşanmasaydı ve Katarlar yalnızca Katoliklerin zihinlerinde ürettikleri ve şeytanlaştırdıkları bir düşman olsaydı ne Katarlar canlı canlı yakılırken ateşe gülerek giderlerdi, ne de Albi Haçlı Seferinin gerçekleştirilmesi ve Engizisyon Mahkemelerinin kurulması gibi ciddi ve büyük neticeler ortaya çıkardı. 


\section{Kaynakça}

Arberth, John. Contesting the Middle Ages: Debates That Are Changing Our Narrative of Medieval History. Taylor \& Francis Group, 2018.

Arnold, John \& Biller, Peter. Heresy and Inquisition in France, 1200-1300. Manchester University Press, 2016.

Arnold, John H. Inquisition and Power. University of Pennsylvania Press, Inc, 2013.

Barbezat, Michael D. Burning Bodies: Communities, Eschatology, and the Punishment of Heresy in the Middle Ages. 2018.

Biget, Jean-Louis, Hérésie et inquisition dans le Midi de la France. Paris: Picard, 2007.

Biller, Peter, "Goodbye to Cathars". Cathars in Question, ed. Antonio Sennis. Boydell \& Brewer, 2016.

Borst, Arno. Die Katharer, Monumenta Germaniae Historica Schriften 12. Stuttgart: 1953.

Brunn Uwe. Des contestataires aux "Cathares" Discours de réforme et propagande antihérétique dans les pays du Rhin et de la Meuse avant l'Inquisition. Paris: Institut d'Études Augustiniennes, 2006.

Bruschi, Caterina and Peter Biller. 2003. Texts and the Repression of Medieval Heresy. Woodbridge, Suffolk, UK: York Medieval Press.

Walker Reid Cosgrove, "Clergy and Crusade: The Church in Southern France and the Albigensian Crusade" Saint Louis University, 2011.

Dondaine, Antonio. “L'hiérarchie Cathare en Italie”. AFP. XIX, 1949, XX, 1950.

Douais, L'Abbe C. Les Albigeois Leurs Origenes Action de L'eglise Au XIIe Siécle. 1. baskı, Paris: Librarie Academique, 1879.

Frasetto, Michael. Heretic lives: Medieval heresy from Bogomil and the Cathars to Wyclif and Hus. London: Profile Books. 2007.

. (ed.)Heresy and the Persecuting Society in the Middle Ages: Essays on the Work of R.I. Moore. Leiden: Brill, 2006.

Hamilton, Janet \& Bernard ve Yuri Stayenov, Bizans Döneminde (650-1405) Hiristiyan Düalist Heretikler. Çev. Leyla Kuzucular. Yurt Kitap Yayın, 2011.

Lambert, Malcolm. Medieval Heresy: Popular Movements from the Gregorian Reform to the Reformation. Oxford: Blackwell, 2002. . The Cathar, Blackwell Publishing, 2007.

Léglu, Catherine, Rebecca Rist, and Claire Taylor. The Cathars and the Albigensian Crusade: A Sourcebook. 2014.

Moore, R. I. The Formation of a Persecuting Society : Authority and Deviance in Western Europe, 950-1250. Blackwell Publishing, 2009.

. The War on Heresy: Faith and Power in Medieval Europe. London: Profile Books, 2014.

64

Milel ve Nihal

inanç-kültür-mitoloji 
Köken Tartışmaları Ekseninde Katarlara Dair Tarih Yazımındaki Güncel Paradiogma... . The Origins of European Dissent. Oxford: 1985.

. The Birth of Popular Heresy. Documents of Medieval History 1. London: 1975.

Obolensky, Dimitri The Bogomils: A Study in Balkan Neo-Manicheism. 2. Bask1. Twickenham: Cambridge University Press, 1972.

Pegg, Mark. The Corruption of Angels: The Great Inquisition of 1245-1246. Princeton University Press, 2009.

. "The Paradigm of Catharism; or, the Historians' Illusion". Cathars in Question. Ed. Antonio Sennis. Boydell \& Brewer, 2016.

. "Principles at Stake: The Debate of April 2013 in Retrospect". Cathars in Question. Ed. Antonio Sennis. Boydell \& Brewer, 2016.

Puech, H., Vaillant A. “Le Traité Contre les Bogomiles de Cosmas le Prétre: Traduction et étude". Travaux publiés par l'Institut d'Études Slaves. XXI. Paris: 1945.

Roach, Andrew, James Simpson. Heresy and the Making of European Culture Medieval and Modern Perspective. Routledge, 2013.

Roach, Andrew. Heresy and Medieval Society, 1100-1320. Harlow: Longman, 2002.

Runciman, Steven The Medieval Manichee: A Study for the Christian Dualist Heresy. Cambridge: Cambridge University Press. 1982.

Russell, Jeffrey "Interpretations of the Origins of Medieval Heresy". Medieval Studies 25/2 (1963).

Sacville, Lucy J. Heresy and Heretics of the Thirteenth Century: The Textual Representations, York: York Medieval Press, 2011,

Söderberg, Hans. 1949. La Religion des Cathares. Almqvist \& Wiksell.

Taylor, Claire Heresy, Crusade and Inquisition in Medieval Quercy, York University Press, 2011.

. Heresy, Crusade and Inquisition in Medieval Quercy. Cambridge: Cambridge University Press, 2013.Théry-Astruc, Julien, “The Heretical Dissidence of the 'Good Men' in the Albigeois (1276-1329): Localism and Resistance to Roman Clericalism," Cathars in Question. Ed. Antonio Sennis. Boydell \& Brewer, 2016.

Townsend, Anne Bradford. Cathars of Languedoc as Heretics: From the Perspectives of Five Contemporary Scholars. Basılmamış Doktora Tezi. Union Institute\&University Cincinnati, Ohio: 2007.

Zerner, Monique (ed.) Inventer l'hérésie? Discours polémiques et pouvoirs avant l'inquisition. Nice: Centre d'Études Médiévales, 1998.

\section{İnternet Kaynakları}

Cathars in Question: A Responce to Pete Biller, http://rimoore.net/2016/11/13/cathars-in-question-a-response-to-pete-biller/ (Son güncelleme: 9 Aralık 2020). https://www.york.ac.uk/res/doat/project/ 